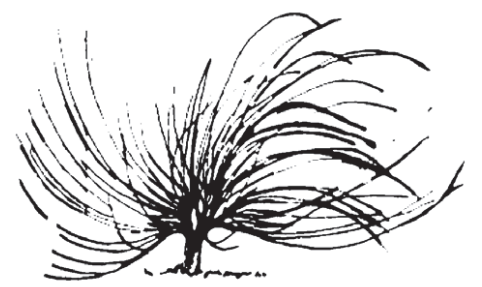

\title{
The Importance of Developing our Teaching Philosophy as EFL Professionals
}

\author{
Jorge Luis Espinoza Campos ${ }^{1}$ \\ Universidad Nacional \\ Heredia, Costa Rica \\ jorespca@yahoo.com
}

\begin{abstract}
Resumen
La creación de una filosofía de la enseñanza es una práctica innovadora y debe de ser una parte significativa para los profesores puesto que en este documento se exponen las experiencias de aprendizaje, las metas, las creencias, el nivel de profesionalismo y de desarrollo personal entre muchos otros elementos. Algunos docentes usualmente escriben una filosofía de su enseñanza únicamente con el fin de realizar una asignación de su escuela o universidad o para completar su currículo vitae. Sin embargo, en la vida real, los docentes no siempre implementan todas las buenas y agradables ideas que están expuestas en sus extractos de reseñas filosóficas de su enseñanza. El objetivo de este trabajo es hacer reflexionar a los docentes en especial a los de inglés como lengua extranjera sobre la importancia de desarrollar esta práctica en nuestro campo para mostrar su aprendizaje y crecimiento a lo largo del tiempo.
\end{abstract}

Palabras clave: profesores, filosofía de la enseñanza, aprendizaje, desarrollo personal, profesionalismo

Recibido: 29 de setiembre de 2013 - Aprobado: 22 de enero de 2014

1 Profesor de Inglés de la Universidad Nacional. Máster en la Enseñanza del Inglés como Segunda Lengua de la Universidad de Indiana en Pensilvania, Estados Unidos. 


\begin{abstract}
Creating our own teaching philosophy statement is an innovative practice, and it should be a meaningful part for teachers since it states the learning experiences, goals, beliefs, level of professionalism and self development among many other elements. Some teachers usually write a teaching philosophy statement just to carry out a school assignment or to complete their résumé. However, in real life, teachers do not often implement all the nice ideas that are stated in their teaching philosophy statement. The goal of this paper is to make EFL teachers reflect on the importance of developing this practice in the foreign language teaching field to show their learning and growth throughout time.
\end{abstract}

Key words: language teachers, teaching philosophy statement, learning, self development, professionalism

\title{
Introduction
}

$\mathrm{D}$ eveloping a teaching philosophy statement is a relatively new teaching practice, and many EFL professionals are not still aware of its importance for their professional, personal and pedagogical growth. Nowadays, in English speaking countries such as the United States and Canada, it is common for educators to develop their own teaching philosophy statement as a part of their personal portfolios. However, the creation of your teaching philosophy should not be just to have a file in your professional portfolio. In my own experience, this was a great practice that motivated me to document my professional expectations, values and beliefs related to teaching and learners. Then, almost two years later, in my last semester of the M.A TESOL program, after reflecting on it, I added new ideas to it that helped me to improve my teaching practices and to recall some good experiences with the learners. For teaching professionals, it is very useful to develop a teaching philosophy to guide and organize their teaching. For example, in my case, I started to establish my own professional goals, teaching methods, and the most important of all was that I developed and documented my identity as an EFL professional. Concretely, this 
paper intends to make educators aware of the importance of creating a teaching philosophy statement to foster their professional, individual and pedagogical growth by answering different research questions such as "Why is it important to develop your own teaching philosophy?," "What should be included in your teaching philosophy?," "What constitutes a good statement?," and "How can you assess your teaching philosophy statement?" In addition, this paper includes some tips and essential aspects that you need to take into account when designing your teaching philosophy and some assessment techniques to evaluate your teaching philosophy meaningfully.

\section{What is a teaching philosophy statement?}

According to Schonwetter, Dieter, Sokal, Friesen, and Taylor (2002), a teaching philosophy statement is "a systematic and critical rationale that focuses on the important components defining effective teaching and learning in a particular discipline and/or institutional context" (p. 84).

Kenny (2008) described a teaching philosophy statement as

a clear and logical statement that communicates what your fundamental values and beliefs are about teaching and learning, why you hold these values and beliefs, and how you translate these values and beliefs into your everyday teaching and learning experiences. (p. 6).

Brookfield (1990) saw a teaching philosophy statement as "a personal vision of teaching; a critical rationale of teaching; sense of purposes of teaching" (as cited in Virginia Teaching Resource Center, 2004, p.1).

\section{Why is it important to develop your own teaching philosophy?}

There are different reasons why EFL professionals should develop their own teaching philosophy statement. A great deal of EFL teachers create their teaching philosophy just to add it to a personal portfolio or to the curriculum vitae in order to get a job. However, these points must not be the main purpose to create a teaching philosophy statement.

Developing a teaching philosophy should have specific goals such as reflecting on your teaching, your students, your methodology, 
your ideals as a teacher, level of professionalism, personal learning, involvement, teaching beliefs, and values among others.

Some concrete relevant reasons to create a teaching philosophy statement are:

- $\quad$ The teacher's beliefs about teaching and learning usually have a positive impact on the students and the classroom environment.

- $\quad$ Teachers tend to implement classroom practices that reflect their philosophical beliefs.

- A well done teaching philosophy helps the instructor to reflect and act appropriately in the classroom.

Additionally, writing a teaching philosophy is quite useful for teachers because it helps them to improve their teaching practices. For example, Coppola (2002) said that developing your teaching philosophy is important because "the teaching statement gives you a starting point for examining your teaching practices, allows you to share your ideas with others, and allows you to monitor the progress of your own development as a teacher" (p. 450).

Coppola (2002, p. 450) also illustrated two more important reasons for writing a teaching philosophy:

1. By writing a teaching philosophy, you also make your thinking public, open to discussion or comment and this is important because it codifies your ideas at a particular time.

2. A teaching philosophy is a great organizer of your teaching.

Murray (1995) gave some other relevant arguments to write a teaching philosophy such as: It helps you to organize your evaluation and to guide your behavior as a teacher, the teaching philosophy allows to document beliefs, values, and teaching approaches, and it contributes to articulate a view of teaching for administrative decision-making (as cited in Goodyear and Allchin, 1998, p.103).

Brookfield (1990, pp. 17-19) also mentioned the importance of developing your teaching philosophy since it can be used for four different purporses: 
1. Personal purpose: it is good that your teaching philosophy reflects why you are doing what you are doing as a teaching professional.

2. Political purpose: Your teaching philosophy needs to show that your position is grounded in a well-developed and carefully philosophy of practice. This helps you to gain respect, which is important for your personal growth in the political area.

3. Professional purpose: Your teaching philosophy needs to show your professional goals to develop an identity that will help you to improve the development of professional strengths among other teachers.

4. Pedagogical purpose: Teaching is about growing and finding new ways to develop your lessons according to the learners' needs, so your teaching philosophy should show what effect you are having on students and on their learning?

There are other important considerations to write a teaching philosophy. For example, in my case, writing my teaching philosophy helped me to develop my identity as a language teacher. Also, writing a teaching philosophy is useful to observe what you do in your lessons, so you learn to monitor your work through time. Besides, creating a teaching philosophy makes you reflect on your behavior, values and beliefs as a teacher. This practice also helps teachers to set new goals and to improve as a professionals and as human beings. In general, one of the main goals of writing a teaching philosophy is to guide your teaching.

\section{What should be included in your teaching philosophy?}

According to Kenny (2008), teaching philosophies are generally structured:

from an introductory statement of your values and beliefs regarding teaching and learning; to a discussion of discipline-specific teaching strategies which demonstrate how these beliefs are put into practice; to future teaching goals which highlight a clear commitment to continuous improvement; and, finally to a conclusion which highlights two or three main points which summarize the TPS and clearly demonstrate your commitment and dedication to teaching and learning. (p. 6). 
Therefore, for writing a good teaching philosophy, it is necessary to organize your personal experience, your values and beliefs, your teaching strategies and your goals for the future including your professional development.

Another way to know what to include in your teaching philosophy is by generating questions like the following ones suggested by Goodyear and Alchin (1998); Ellis and Griffin( 2000), Kaplan, Meizlish, and O'neal (n.d.); and Schonwetter et al. (2002).

\begin{tabular}{|ll|}
\hline 1. & Why do you teach? \\
\hline 2. & $\begin{array}{l}\text { What are your teaching approaches? What is your teaching style? What teach- } \\
\text { ing strategies do you most often rely upon? Why? }\end{array}$ \\
\hline 3. & What are your standards or criteria for effective teaching? \\
\hline 4. & What do you find rewarding about teaching? \\
\hline 5. & What is unique about your teaching? \\
\hline 6. & What characteristics describe an effective university learning environment? \\
\hline 7. & $\begin{array}{l}\text { What are your strengths and skills as a teacher? What strategies have been partic- } \\
\text { ularly effective in terms of student learning and engagement? }\end{array}$ \\
\hline 8. & How do you establish rapport with your students? \\
\hline 9. & $\begin{array}{l}\text { What areas of your teaching require improvement? Why? How do you intend } \\
\text { to improve? }\end{array}$ \\
\hline 10. & $\begin{array}{l}\text { What strategies have you used to evaluate and gather feedback on the effec- } \\
\text { tiveness of your teaching? }\end{array}$ \\
\hline 11. & $\begin{array}{l}\text { What have you learned about yourself as a teacher? Have your students, peers } \\
\text { or the instructor provided direct feedback? }\end{array}$ \\
\hline 12. & Which teaching tasks do you find most challenging? \\
\hline 13. & What is the most significant thing that has happened to you as a teacher? \\
\hline 14. & What is your proudest teaching moment? Why? \\
\hline 15. & $\begin{array}{l}\text { What teaching moment do you feel most dissatisfied about? How can you } \\
\text { improve upon this? }\end{array}$ \\
\hline 16. & What are your future teaching goals? \\
\hline 17. & What sorts of skills do you deliberately attempt to teach in your classes and why? \\
\hline 18. & How do you evaluate whether you've accomplished your teaching goals? \\
\hline
\end{tabular}

\section{What Constitutes a Good Statement?}

Kenny (2008) thought that a teaching philosophy should communicate personal and philosophical beliefs about teaching and learning. It usually demonstrates a strong connection to scholarly research and literature in 
higher education, and it shows a clear commitment to continual improvement. Therefore, teaching philosophies change through time, which provides direction, meaning and purpose to your teaching and learning experiences. Based on your teaching roles, you can prepare a teaching philosophy based on your fundamental beliefs about teaching and learning with a clear focus on your future teaching goals (Kenny, 2008).

Mike Akitson (2000), a member of the Teaching Support Center of the University of Western Ontario, suggested that a well-done teaching philosophy statement should include the following points: Personal Reflection, citing specific teaching tactics, a philosophical background of the pedagogical approach and identification of goals.

According to Kaplan, Meizlish and O'neal (2007), successful teaching philosophy statements include the following characteristics:

- They offer evidence of practice: This is an important aspect to be included in your teaching philosophy because it shows your knowledge and learning based on your teaching experience.

- They convey reflectiveness: A teaching philosophy should show that the instructor is thoughtful about what he does. Reflectiveness helps the instructor to be ready to face future instructional challenges and ready to set new goals for the future.

- They communicate that teaching is valued: This an important point to develop a good teaching philosophy because the instructor needs to demonstrate his/her enthuasiasm and commitment towards teaching.

- $\quad$ They are student- or learning-centered, attuned to differences in students' abilities, learning styles, or levels: It is relevant to include the ways you work with students and how you help them to get involved considering their abilities (Kaplan, Meizlish, \& O'neal, 2007). Additionally, it is important to specify in the teaching philosophy statement how you as an educator take into account the students' learning styles and preferences.

\section{How to assess your teaching philosophy statement?}

After developing your teaching philosophy statement, it is important to know how you can assess it so that you can use it to guide your teaching practices and to improve your learning as a professional. 
Assessment of your teaching philosophy plays an important role because it promotes personal and professional growth, development, and renewal. For this reason, teachers should try to update it and include their new teaching methods, practices, experiences and put into practice in the classroom what it is stated on the teaching philosophy statement.

Kaplan, Meizlish and O'neal (2007) presented a rubric that can be used to assess and compose your teaching philosophy statement. This rubric includes five categories: goals for student learning, enactment of goals, assessment of goals, creating an inclusive learning environment and structure, rhetoric, and language (Kaplan, Meizlish and O'neal, 2007, p. 7). The first three categories expressed by Kaplan et al. (2007) point out the achievement of the goals, methods and assessment techniques. The goal of focusing on these three aspects is that the teaching philosophy provides professors "a clear direction for future development and ensuring that the teaching statement is not merely a rhetorical exercise, but a useful contribution to your development as a teacher" (Kaplan, Meizlish and O'neal, 2007, p. 3).

Schonwetter et al. (2002) suggested that your teaching philosophy statement should be assessed by a partner so that you can get detailed feedback, exchange and share ideas in ways that your teaching statement can contribute positively to the development of your teaching. They also proposed a framework to evaluate teaching philosophies based on a critical evaluation of the correspondence of the teaching beliefs, practices, goals and how teaching develops through time. The purpose of this evaluation is to guide teaching professionals in four domains of the teachers' lives: the personal, the public, the professional and the pedagogical. To cover all the points previously described, Schonwetter et al. (2002) encouraged teachers to assess their teaching philosophy statement based on the following areas teaching and learning definitions and beliefs: view of the learners and student development, student-teacher relationship, teaching methods and evaluation impact on the learner. Lastly the center for Teaching and Learning of the University of Minnesota (2008) encouraged self and peer assessment of your teaching philosophy checking tone and content and making sure that the writer has provided contextual examples to support his/ her main points. 
Based on all the ideas and points previously mentioned in this essay professors can use the following checklist that I have created to assess, update and improve their teaching philosophy statements.

\section{Teaching Philosophy Assessment Checklist}

\begin{tabular}{|c|c|c|c|}
\hline Question & Yes & No & Needs Improvement \\
\hline \multicolumn{4}{|l|}{ CONTENT } \\
\hline \multicolumn{4}{|l|}{$\begin{array}{l}\text { Does it mention clearly the main goals in terms of } \\
\text { teaching and personal learning? }\end{array}$} \\
\hline \multicolumn{4}{|l|}{ Does it state your values as a teacher? } \\
\hline \multicolumn{4}{|l|}{ Does it refer to your teaching style? } \\
\hline \multicolumn{4}{|l|}{$\begin{array}{l}\text { Does it include meaningful content related to your } \\
\text { teaching experience? }\end{array}$} \\
\hline \multicolumn{4}{|l|}{ Does it describe your teaching methodology? } \\
\hline \multicolumn{4}{|l|}{$\begin{array}{l}\text { Does it communicate your beliefs regarding } \\
\text { teaching and learning? }\end{array}$} \\
\hline \multicolumn{4}{|l|}{$\begin{array}{l}\text { Does it mention the teaching strategies and } \\
\text { procedures used in class? }\end{array}$} \\
\hline \multicolumn{4}{|l|}{$\begin{array}{l}\text { Does it show what positive achievements you have } \\
\text { had as a teacher? }\end{array}$} \\
\hline \multicolumn{4}{|l|}{ Does it reveal your identity as an educator? } \\
\hline \multicolumn{4}{|l|}{ Does it give importance to the role of the students? } \\
\hline \multicolumn{4}{|l|}{$\begin{array}{l}\text { Does it explain the different teaching contexts you } \\
\text { have worked? }\end{array}$} \\
\hline \multicolumn{4}{|l|}{ Does it reveal your ideals as a teacher? } \\
\hline \multicolumn{4}{|l|}{$\begin{array}{l}\text { Does it demonstrate awareness of the different } \\
\text { problems you may encounter in your teaching? }\end{array}$} \\
\hline \multicolumn{4}{|l|}{ Does it reflect your identity as a teacher? } \\
\hline \multicolumn{4}{|l|}{ Does it describe the different types of learners? } \\
\hline \multicolumn{4}{|l|}{$\begin{array}{l}\text { Does it specify how research has influenced your } \\
\text { teaching? }\end{array}$} \\
\hline \multicolumn{4}{|l|}{ Does it include your future plans as a teacher? } \\
\hline \multicolumn{4}{|l|}{$\begin{array}{l}\text { Is your teaching philosophy appropriate for your } \\
\text { teaching context? }\end{array}$} \\
\hline \multicolumn{4}{|l|}{ STRUCTURE AND FORMAT } \\
\hline \multicolumn{4}{|l|}{ Does it have a clear focus? } \\
\hline \multicolumn{4}{|l|}{ Does it provide an understandable description? } \\
\hline \multicolumn{4}{|l|}{$\begin{array}{l}\text { Is the language used clear and appropriate for the } \\
\text { readers? }\end{array}$} \\
\hline \multicolumn{4}{|l|}{$\begin{array}{l}\text { Does it show a good use of grammar structures, } \\
\text { punctuation and spelling? }\end{array}$} \\
\hline $\begin{array}{l}\text { Does the writer use transition words, headings and } \\
\text { subtitles appropriately? }\end{array}$ & & & \\
\hline
\end{tabular}




\section{Conclusion}

This research has been quite helpful to expand my teaching professional knowledge. In fact, writing a teaching philosophy statement is a great practice for all teachers since by doing it they learn to reflect about their work as teachers and they also put into practice their ideals in terms of teaching and learning. In addition, the teaching philosophy statement is a good way to think about your beliefs, values, expectations and goals as an EFL instructor. This is important because teachers need to have a clear idea of what to do in their job. I personally recommend this interesting practice because in my case, it was quite useful to improve the quality of my work, and I can say that thanks to my teaching philosophy now I have a stronger identity as a teacher. This activity has helped me to learn day by day from what I do and how I can help my students. Besides, writing a teaching philosophy statement is beneficial for teaching professionals because in this document educators can think about their own learning, professional growth and their goals for the future. This practice is also a great contribution to develop your critical thinking, understand your responsibilities and to reflect about the role of the students. For this reason, it is necessary for teachers to consider different elements before writing a teaching philosophy statement.

Then, it is very important to assess your teaching philosophy statement constantly in order to improve the quality of your teaching, learning and level of professionalism based on the experiences and challenges faced. Moreover, it is good to evaluate your teaching philosophy statements with other colleagues so that you can exchange ideas and learn from other professionals. According to Grundman (2006), it is good to discuss your teaching philosophy with others because "the input and reactions from other instructors will enable you to clarify your own beliefs and determine how to express them most effectively" (p. 1329). This practice can also offer some useful feedback that can influence positively your teaching. For example, the recommendations given to you may offer some solutions to the problems that you have encountered throughout your teaching experience.

Finally, I encourage all the teaching professionals to update their teaching philosophy statements frequently since the teaching beliefs, learners, goals, values, methods and teachers' roles change through time and it is very meaningful to add new ideas to it. In general terms, we can conclude that a well done teaching philosophy statement helps teachers to accomplish their goals and be better professionals. 


\section{References}

Atkinson, M. (2000). Your teaching philosophy. Retrieved on from http://www.uwo. ca/tsc/resources/publications/newsletter/selected_articles/your_teaching_philosophy.html

Brookfield, S. (1990). The skillful teacher. San Francisco, CA: Jossey-Bass.

Center for Teaching and Learning. (2008). Assessing your teaching philosophy draft. Retrieved from http://www1.umn.edu/ohr/teachlearn/tutorials/philosophy/assess/index.html

Coppola, B. (2002). Writing a statement of teaching philosophy: Fashioning a framework for your classroom. Journal of the College of Science Teaching 31.7, 448-53. Retrieved from http://galois.math.ucdavis.edu/UsefulGradInfo/HelpfulAdvice/ProfDev/Coppolla_TeachingStatement.pdf

Goodyear, G. E. \& Allchin, D. (1998). Statements of teaching philosophy. Retrieved from http://sunconference.utep.edu/CETaL/resources/stofteach

Grundman, H. (2006). Writing a teaching philosophy statement. Notices of the AMS. 53(11) ,1329-1333. Retrieved from

http://www.koreatesol.org/sites/default/files/pdf/Writing\%20a\%20Teaching\%20Philosophy\%20Statement_0.pdf

Kenny, N. (2008). Developing a statement of teaching philosophy. Retrieved from http://www.tss.uoguelph.ca/id/ta/tapdfs/A\%20Workshop\%20on\%20Developin2a\%20Statement\%20of\%20Teaching\%20Philosophy.pdf

O'neal, C., Meizlish, D., \& Kaplan, M. (2007). Writing a statement of teaching philosophy for the academic job search. Retrieved from http://www.crlt.umich.edu/ publinks/CRLT_no23.pdf

Schonwetter, D. J., Sokal, L., Friesen, M., \& Taylor, K.L. (2002) Teaching philosophies reconsidered: a conceptual model for the development and evaluation of teaching philosophy statements. The International Journal for Academic Development, 7, 83-97.

Virginia Teaching Resource Center. (2004). Developing your reflective teaching statement. Retrieved from http://trc.virginia.edu/Programs/TPT/PDFs/S4_RTS.pdf 